\title{
Belgeo
}

Revue belge de géographie

$1 \mid 2007$

The advanced service sectors in European urban regions

\section{Location dynamics of business services in the urban landscape of Copenhagen: Imaginary spaces of location}

Dynamiques de localisation des services aux entreprises dans le paysage urbain de Copenhague: espaces imaginaires de localisation

\section{Lars Winther}

\section{OpenEdition}

\section{Journals}

Electronic version

URL: http://journals.openedition.org/belgeo/11650

DOI: $10.4000 /$ belgeo. 11650

ISSN: 2294-9135

\section{Publisher:}

National Committee of Geography of Belgium, Société Royale Belge de Géographie

\section{Printed version}

Date of publication: 1 January 2007

Number of pages: $51-72$

ISSN: 1377-2368

\section{Electronic reference}

Lars Winther, «Location dynamics of business services in the urban landscape of Copenhagen:

Imaginary spaces of location », Belgeo [Online], 1 | 2007, Online since 09 December 2013, connection on 01 May 2019. URL : http://journals.openedition.org/belgeo/11650 ; DOI : 10.4000/belgeo.11650

This text was automatically generated on 1 May 2019.

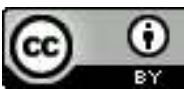

Belgeo est mis à disposition selon les termes de la licence Creative Commons Attribution 4.0 International. 


\section{Location dynamics of business services in the urban landscape of Copenhagen: Imaginary spaces of location}

Dynamiques de localisation des services aux entreprises dans le paysage urbain de Copenhague: espaces imaginaires de localisation

\section{Lars Winther}

I would like to thank Høgni Kalsø Hansen, Christine Benne Skytt and anonymous referees for very useful and constructive comments on an earlier version of the paper. The usual disclaimers apply. The research was funded by the COMET project (see below) and Centre for Strategic Urban Research (www.byforskning.dk).

\section{Introduction}

1 There is a current resurgence of the large cities and metropolitan regions in many European countries. This resurgence is also evident in Denmark where Copenhagen has experienced a period of growth since the mid-1990s. The resurgence refers to two central processes of spatial economic restructuring (Storper and Manville, 2006). First, the economic and industrial revitalization of the city-region level, including the expansion into the surrounding countryside, creates new economic geographies but also a transformation of the urban division of labour and the location dynamics of firms. The second resurgence process is the renewed reinforcement of the central city as an important space of economic growth, especially concerning advanced business services.

2 The resurgence of the large cities happened alongside a long term industrial transformation of the city-region. In the case of Copenhagen, the transformation has been on the one hand dominated by de-industrialisation and restructuring of the remaining manufacturing industries and on the other hand by the coming service and knowledge-based economy (Winther, 2004). The paper examines the industrial 
restructuring and location dynamics of the urban economy with an exclusive focus on business services and the past decades of economic growth in Copenhagen. Business services have grown rapidly since the 1970s, including research and development activities, legal activities, consultancy, advertising but also more traditional activities such as cleaning, photographers, designers, translation etc. The first mentioned business service activities have become crucial in the knowledge-based economy.

In the knowledge economy, the competitiveness of firms depends on their ability to innovate, improve their productivity (process innovation, including new forms of organisation), product quality or produce new products (David \& Foray, 2002). The innovation process is perceived as an interactive and relational process which is highly complex and includes interaction between users and producers and between producers and regional institutions such as the labour market and regional public and semi-public organisations (Storper, 1997). A critical aspect of the innovation process is knowledge and the understanding of knowledge creation as an interactive, relational learning process (Amin \& Cohendet, 2004). The recent wave of outsourcing in firms has created a marked growth in knowledge intensive business services (KIBS), giving the sector a central position in the production networks facilitating and producing knowledge. Thus, the business service firms have come to play a vital role in the innovation process and production of knowledge because of the disintegration of the production process and the increasing use of outsourcing, outplacement and projects; therefore the sector also has a major role in the overall competitiveness of firms, regions and metropolises. In a Danish urban and regional context, we know relatively little about the dynamics of KIBS and its location dynamics in the urban landscape in the past decades (Winther et al., 2005).

It has been established that a large process of suburbanisation of services took place in the 1980s of both back-office function and knowledge intensive business services. Inner cities were increasingly marked by the spatial restructuring and relocation of large parts of the service sector towards suburban areas, and they were reduced to have mainly administration, housing, cultural functions, retail and HQs. The growth of the service sector produced new location patterns inside the city-regions. One of the central new patterns was business to business activities and back-office functions located in suburban sub-centres that rose in the post war years and later also on the edge of the city-regions. In Copenhagen the development took place in different parts of the urban landscape, creating a more polycentric urban landscape (Illeris, 1997). Since the early 1990s, Copenhagen has experienced a period of economic growth and job creation driven by service industries. The location dynamics of the growth in the 1990s prove to be more ambiguous than patterns of the 1980s. New location dynamics involve concentration in the central part of the urban landscape, extension of existing locations and growth in new locations. The paper provides evidence of the new complexity of location in the urban landscape. It sets out to answer the following questions. What are the main growth patterns and location shifts of business services in Copenhagen? What are the reasons for the different dynamics of the 1980s and 1990s? Has the new complexity to do with firms' perception of location? To do so, the paper presents two interrelated analyses on the location dynamics of business services in the urban landscape of copenhagen based on the results and data from the COMET project ${ }^{1}$.

5 First, a unique set of employment data from the register based databases at Statistics Denmark and COMET databases is used to describe the location patterns and shifts in business services. Data is employment numbers and covers full range for the day time 
population. In this article three variables related to employment are used: geography, industry and education. The industry variable represents a 2-digit categorization of industry codes based on the NACE nomenclature. Further, to increase the knowledge of the division of labour and location dynamics, the number of employees with a university degree (ISCED 5A, 6) as one dimension of the importance of human capital is applied. This is an indication of the part of the business services that is knowledge intensive, but only the part that uses formal education. Business activities are highly complex, and the use of employees with university degrees can point to one of the central divisions of labour in the urban landscape of Copenhagen.

6 Secondly, the paper presents the results of a large survey made in 2003 as a part of the COMET project. The paper uses the results to provide an understanding of the firm's perception of location, and it illustrates that firms in different key industries within business services have quite different perceptions of spaces of location. This is defined as imaginary spaces of location (Winther \& Hansen, 2006). The imaginary spaces of location must not be understood as mere facts or exact location preferences. They are socially constructed perceptions of the preferences of location. They originate from the interviewee (representing the firm) and are based on, for instance, personal beliefs, wishful thinking or real thought-through preferences. They are, all in all, representations of the perception, experience and interpretation of the location preferences by the firm: the firms' representation of space. The survey reveals that the firm's imaginary spaces of location are very different by industry, pointing to the fact that many location strategies are forming the current economic spaces of business service. The imaginaries provide one perspective of the new complexity of location.

7 The next section, section 1, provides a definition of the urban landscape of Copenhagen and an overview of the intra-urban division of labour and an outline of the transformation of the urban landscape of Copenhagen, pointing to the two major processes of the current transformation: the expansion of the urban landscape and the transformation of the industrial structure towards a service and knowledge-based economy, including the difference of the urban economic crisis in the 1980s and the growth of the 1990s. Section 2 discusses the economic geographies of the urban landscape in the nexus between regionalist and relationalist accounts. The section introduces the imaginary spaces of location. Section 3 provides an analysis of the spatial restructuring of business services in the past decades. Section 4 uses empirical evidence from a large survey to explain the new location dynamics of business services in Copenhagen and examine the imaginary spaces of location in five key industries. Section 5 concludes the paper.

\section{The Urban Landscape of Copenhagen}

8 The city-region has become fundamental in the modern economic landscape (Scott, 2002), and the current economic and industrial resurgence is transforming and shaping the economic urban landscape through two central processes. The first major process is the expansion of the metropolitan areas in Europe (Borsdorf, 2004). City-regions include large parts of the countryside which have become more and more integrated in the urban economy (Sieverts, 2003). The transformation has resulted in an urban landscape with higher degree of complexity. As a result, new spaces of relations and flows have emerged changing the divisions of labour and transforming existing economic and industrial 
spaces. This development has been theorised in many directions: concepts such as metropolisation, edge cities, post-suburbia and networks of urban networks, Netzstadt or Zwischenstadt have been used in order to understand the expansion of the modern cities into the peri-urban areas and the rescaling of the city structure (Ascher, 2002; Phelps and Parson, 2003; Bontje, 2004; Borsdorf and Zempri 2004, Sieverts, 2003).

The second major transformation is the changes of the industrial structure of the cities, including the immense de-industrialisation and the coming of the service and knowledgebased economy. The service and knowledge-based economy has shaped new divisions of labour and location dynamics, producing a polycentric urban landscape. Polycentrism, that is, the existence of multiple centres in the urban region with increased specialisation, and the expansion of the urban region into the surrounding country-side have resulted in a new, more multifaceted urban landscape (Kloosterman and Musterd, 2001; Phelps and Parsons, 2003; Hidding et al., 2000). This is also evident in Copenhagen.

\section{The Urban Landscape of Copenhagen}

In order to examine the location dynamics of business services, the definition of the urban landscape of Copenhagen provided by the COMET project is used. It divides the metropolitan area into four main zones, see Figure 1. Zones 1, 2 and 3 make up the builtup area based on the N.U.R.E.C. (1994) classification. Zone 4, however, is defined by other criteria and make up a transition zone that borders the built-up area. Zone 4 is included in order to capture the process of the expansion of the city-region into the country-side.

Figure 1. Copenhagen - delimitation.

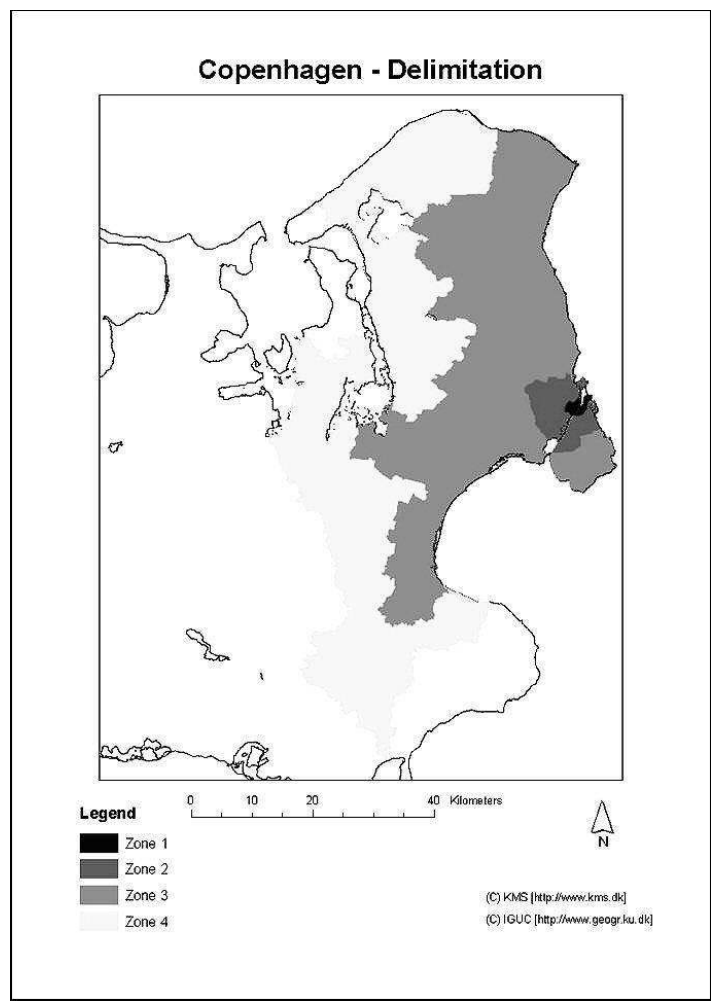

11 Zone 1 is defined as the core of the agglomeration. In the case of Copenhagen, zone 1 is demarcated by the lines of the medieval city. Zone 2 is the rest of the core city. The area 
consists of the remaining part of the municipality of Copenhagen and the municipality of Frederiksberg. Frederiksberg is situated as an independent enclave within the municipality of Copenhagen. Zone 2 is an important area for businesses, retail and housing. It is closely connected to the inner city in terms of economical processes. The zone can in some ways be seen as consisting of both inner city functions as well as suburban functions, making it a transition zone between the central zones and the suburban zone. In the paper, zones 1 and 2 are examined together and referred to as the central city. Zone 3 is the suburban zone. The zone is on the one hand a place for industry, housing, shopping, entertainment, day-care, schools and administration and everyday life, and, on the other hand, it has within the last 25 years provided new industrial sites for service industries, including back-office functions and many business to business activities (Hansen et al., 2003). The suburban zone consists of many city centres often related to former villages. Zone 3 is bordered by zone 4 where the built-up city ends. Zone 4 is a transition zone between the built-up area and the rest of Zealand. It is the area within a 10 kilometre buffer zone starting where Zone 3 ends. Only municipalities that have the centre of gravity of their built-up area within the buffer zone qualify. Thereby the transition zone comes to consist of municipalities that have the main urban activities in less then a 10 kilometres distance from the built-up area. The definition provided here defines the transition zone as in between the built-up area and the countryside. It indicates a zone that is highly integrated into the urban landscape of Copenhagen as a place of residence and a place of business. It allows an examination of the expansion of the Copenhagen urban landscape (Winther \& Hansen, 2006).

To understand the dynamics of the economic urban landscape of Copenhagen, it is important to know that the zones are crossed by five corridors of urban growth with green spaces in between, reflecting the Finger plan that has been a guideline for urban planning since the early post-war years (Andersen et al., 2003). The five corridors are important in order to understand the urban division of labour and location dynamics because they are highly specialised. The focus of the paper is on the four zones but it keeps the corridors in mind when analysing the new location dynamics and divisions of labour.

\section{The Industrial Transformation of Copenhagen: Recession and Growth}

13 The second major transformation is the economic and industrial transformation of Copenhagen since the economic recession in the early to late 1970s. From being the national industrial (manufacturing) centre in the early post war years, Copenhagen experienced a long and considerable phase of de-industrialization, e.g. loss of manufacturing jobs. The de-industrialisation began in the 1960s and strengthened during the economic recession of the 1970s and continued strongly throughout the $1980 \mathrm{~s}$ (Maskell, 1986; Winther, 2001). The process of de-industrialisation continues today, but not at the same rate as in the 1970s and 1980s. Several studies have revealed that the deindustrialization process also was a restructuring process changing the structure of the manufacturing sector. On one hand, Maskell (1986) showed that the job loss was mainly due to firm closure and downsizing in the traditional manufacturing industries. On the other hand, Breum (1991) and Jakobsen (1993) proved that in the 1980s there was a significant start-up of new high-tech firms. The manufacturing sector continued its 
decline in the central parts of the city (zones 1 and 2), but in zones 3 and 4 the secondary sector grew, especially in zone 4 (Hansen \& Winther, 2006). Winther \& Hansen (2006) showed that the growth in the transition zone is constituted by a range of different industries.

The service sector grew in the 1970s and 1980s in the Copenhagen region, but the deindustrialisation was stronger and there was a general loss of jobs in the 1980s and early 1990s (Winther, 2004). The main reason for the loss of jobs was the continuing deindustrialisation of the central city (zones $1 \& 2$ ) while the rest of the urban landscape had a total increase in employment by workplace. The growth outside the central city was even higher than the national average and mainly in a range of services. Bell's (1999) and Gershuny's (1978) seminal books initiated several studies of the coming of the service economy in Denmark (Illeris, 1987a; 1987b; 1996). Most studies of the economic geography of services in Denmark, however, examines producer and business services based on the observation that producer and business services had become economically more important (in terms of jobs) in the 1970s and 1980s, but the service sector went through a general restructuring (Hansen \& Winther, 2006). Retail and wholesale trade grew slowly in the 1980s and 1990s with a minor loss of jobs in the central city. Likewise, there was a restructuring of finance and insurance with a movement from the inner city towards zone 3 - the suburbanisation process (Illeris, 1997). The sector had a relatively stable development in employment. The public sector had a loss of jobs in the 1980s, especially in zone 1 but the growth was very slow in the 1990s. Transport and communication had a decline in employment by workplace in the 1980s. Like finance, the insurance sector experienced a suburbanisation process with loss of jobs in zones 1 and 2 and growth in zones 3 and 4 . In the 1990s, all zones gained jobs, especially zone 1 (telecommunication) and land transport in zones 3 and 4. Finally, business services grew fast in both the 1980s and 1990s, especially in zones 3 and 4 in the 1990s, while the core of the urban landscape had the highest growth rate in the 1990s.

The 1990s was markedly different from the 1980s. A long period of economic growth and job creation in Copenhagen had been characteristic from the mid 1990s. It was not only because the local and national governments made several large-scale investments in infrastructure (the fixed link to Sweden, the Örestad development and the metro lines) and cultural facilities (European Cultural Capital 1996 with its revitalisation of the city's cultural institutions) but also in terms of employment in the service sector related to the rise of the service and knowledge-based economy. The main drive behind the job creation was a variety of service industries, but the high growth was mainly due to a broad range of business and producer services, the public sector including child care, elder care and education, the cultural and experience economy and the construction sector (Winther, 2004).

\section{Location Dynamics of the Urban Landscapes: Imaginary Spaces of Location}

16 The economic urban landscape is constituted by a range of heterogeneous and differentiated spheres, e.g. physical and material structures in space, organizational and institutional set-ups and the geography of technology, knowledge and learning. This creates path-dependency where former processes, relations and structures influence 
current urban forms. The process of path-dependency points to the history of the economic landscape. An important feature of capitalism is that it produces and reproduces different geographies in different industries and sectors at different scales. Examples of these are changes in local labour markets, new housing patterns and new location patterns of industries. These changes again produce new geographies of difference and interdependencies such as new economic relations and networks, i.e. new relational geographies and new divisions of labour and location dynamics. The rise of the knowledge-based economy produces new location patterns as the prerequisites for the survival and competitiveness of regional firms change.

\section{Location in Place: Geographical Proximity or Relational Propinquity?}

17 A recent focus of urban and regional studies has exactly been on the knowledge-based economy and, hence, knowledge creation, learning and the understanding of how locations underpin the competitiveness of firms. This direction has moved from the more neoclassical understanding of localisation and urban economies to use economic network theories and economic sociology to recognizing the regional social and cultural elements as explanatory factors in order to analyse the regional innovation systems, innovation potential and the competitiveness of firms. Concepts such as social capital, trust, norms and conventions have become central analytical categories explaining (uneven) regional development through "traded and untraded interdependencies" (Storper, 1997) or knowledge spill-over mechanisms. It is necessary to address these concepts to understand the concept of imaginary spaces: the assumption that economic agents are not necessarily acting rationally in a strict economic way but they are shaped by their social relations and cultural embeddedness.

The knowledge direction in urban and regional studies draws heavily on institutional and evolutionary economic theories and the vast innovation literature. Three main strands can be identified (Asheim and Mariussen, 2003). The first strand of research emphasises institutions, formal and informal rules, norms and legislation as prerequisites for economic development, knowledge production and innovation. The second strand has a focus on geography pointing to localized learning, geographical proximity, clusters and agglomeration economies. This literature stresses the necessity of face-to-face contact and regards socio-cultural proximity as fundamental for innovation and knowledge transfer between the economic agents. Clusters, industrial districts and regional systems of innovations are the main interest. The latter is an outcome of the third strand concerning the innovation system which underpins the innovation process (Lundvall, 1992; Edquist, 1997).

19 Two positions dominate the current debate in the geographical strand: a localist/ regionalist position versus a relational position (Peck and Yeung, 2003). The regionalist position has had a marked position in recent years and attributes geographical proximity a vital role for the production of knowledge (Asheim, 1996; 2002), Morgan (1997), Storper (1997), Cooke and Morgan (1998), Maskell and Malmberg (1999) and Gertler (2003). The region is often conceptualised as a space in which the institutional framework of learning processes and knowledge production is produced and reproduced, and the common culture, institutions, norms and values are claimed to be decisive for trust among economic actors (people and firms). 
20 Especially the analysis of agglomeration economies and clusters has been in focus in recent years - see for instance Asheim et al. (2006) for a recent summary - including an emerging critique (Martin and Sunley, 2003; Amin, 2003). The analysis of geographical clusters focuses on the identification of local or regional capabilities. The theoretical framework gives emphasis to growth industries, the costumer and supplier networks and the general institutional set-up which are created within clusters but external to firm advantages. The dynamics have been theorized thoroughly but empirical evidence is needed (Malmberg and Maskell, 2002; Malmberg, 2003).

21 The relational position emphasises relational propinquity and is associated with Amin's (2003; 2004), Amin and Thrifts' (2002) and Amin and Cohendet's (2004) analyses of globalization, urban and regional development, urban change and production of knowledge. In Amin and Thrift (2002), location is understood as a situated, distanciated network. For instance, they argue that relational or organizational propinquity is more important than geographical proximity in transfer of tacit knowledge. Amin and Cohendet's (2004) discussions of the production of knowledge in firms illustrate the relational position. They focus on the firm being the locus of knowledge production rather than the region. Doing so, they see different factors underpinning the knowledge producing processes. They do not exclude geography as an important factor shaping firm networks, but the space in which the firms operate cannot be reduced to a matter of geographical scales. The firm's network is constituted by the firm's relations, and, hence, the analytical focus should be on the space which is defined by the firm relations, i.e. the spatial extension of the relations.

22 Recently, Bathelt et al. (2004) have promoted a theoretical sketch which discusses the local production of knowledge as a product of local buzz or as a presence of actors embedded in a geographical community, and knowledge stemming from channels of pipelines of communication which are linked to places outside the community. Thus, an increasing return to location of economic activity is not only restricted to local spill-over effects but also to the relational spaces of firms that stretch beyond the territorial entities. Relational propinquity gives a new insight to the competitiveness and location of firms with its focus on relations. However, to understand the industrial and location dynamics, it is vital to recognise how places underpin the relational and organisational spaces. It is not within the present framework to examine these relational and organisational spaces. However, the analysis presented below indicates that inclusion of the relational spaces in the analysis may raise different questions of the location dynamics.

\section{Imaginary Spaces of Location}

23 The conclusion above contradicts the traditional urban hierarchic orders, rational choice and Homo Economicus rationality of the neoclassical inspired location theory (Barnes, 1996). Moreover, the advantage and scope of agglomeration have been the main argument in explaining logics of location. Social parameters such as family ties and environment have seldom been adapted. In empirical studies the main line of reasoning has been economic factors perceived as absolute neutral categories. Instead of understanding locational preferences of firms as absolute categories and as a result of economic rationality, the concept of imaginary spaces of location was introduced to point to the social embeddedness of economic action (Winther \& Hansen, 2006). Imaginary 
spaces of location are the expressed locational preferences of the firms at a particular point in time. These imaginary spaces must not be understood as facts or exact preferences. They are social constructs of the interviewee (representing the firm) based on for instance personal beliefs, wishful thinking, political conviction, the discursive practice of interest groups or real thought-through locational preferences. The locational preferences can be related to a variety of discourses arising from multiple rationalities (Ettlinger, 2003), i.e. economic, social or cultural embedded rationalities. The location preference of a firm (economic rationale) may for instance be related to values of residence (social or cultural rationale). The imaginary spaces of location are all in all representations of the perception, experience and interpretation of locational preferences by the firm (or the interviewee representing the firm). They do not necessarily relate to the reasons of the original location of the firm but to the current understanding/representation of the location. For example, a category such as 'prestige', which has been used extensively in studies on location preferences, is by far an absolute category as it often appears. Different firms have different perceptions of prestige and hence ascribe different values to prestige. International law firms may find prestige in waterfront offices, while IT HQs find green fields prestigious. The importance and the qualitative content of prestige may also very well change over time. This has to do with imaginaries. Imaginary spaces of location have importance also when it comes to relocation of firms. To a high degree, it is the perception of economic space that forms the firm's location dynamics and their understanding of competitiveness. The survival and competitiveness of the firm do not necessarily correspond to imaginaries of the firms. A firm may perceive a certain location as a competitive advantage, but the location may in reality reduce the competitiveness of the firms in question. This will eventually appear through the section mechanism on the market, the birth and death, relocation or expansion and downsizing of firms.

\section{The Location Dynamics and Transformation of Business Services in the Urban Landscape of Copenhagen}

24 In Denmark, Pedersen (1986) and Illeris (1987b) concluded that business services were located overwhelmingly in Copenhagen in the 1970s and 1980s. Aarhus - the second largest city in Denmark - was the only city outside Copenhagen with a location quotient that was larger than 1 . Several other studies have pointed to the fact that Copenhagen was the main business services centre in Denmark in the 1970s and 1980s. They also expose the fact that the municipalities with the highest growth rates in business services employment were mainly municipalities in the Western and Southern Jutland. The section presents the first take on the location dynamics of business services. First a review based on existing studies that emphasise the process of suburbanisation in the 1980s is presented. The second part provides an analysis of the changes in the 1980s and 1990s based on employment by workplace data. The last part of the section emphasises the diversity of the location dynamics in the 1990s, using employment data by workplace and formal education as an indication of a high degree of knowledge intensity. 


\section{Location Dynamics of Business Services in Copenhagen in the 1980s}

25 A series of studies have provided a more profound insight into the location dynamics of the business services in Denmark and Copenhagen in the 1980s. Fich \& Larsen (1988) examined producer services. The study revealed that producer services in terms of employment had an over-representation in the core region of Copenhagen (zones 1 and 2), in 1985 accounting for 25 percent of the total employment (producer services accounted for 8 percent of the national employment). The study provided statistical evidence which revealed that producer services were the sole growth industries in the core region of Copenhagen in the early 1980s. Further, the study showed that the employment growth in producer services between 1982 and 1985 was almost identical in the core of Copenhagen and the rest of Denmark. Based on qualitative interviews with firms, the study provided explanations of the centralised location pattern that the producer services exhibited. The main conclusion was that producer service firms located or wished to locate in the centre of Copenhagen due to convenience rather than specific location needs which only the core could provide. Therefore, the producer services industries were oriented towards the core but not dependent on the location in the core.

Another important lesson stemming from the Danish business and producer service research is that the sector is very heterogeneous. Different industries follow different development paths and have different location dynamics. This was already stated by Nielsen \& Planstyrelsen (1988) and later stressed in Illeris (1997) and Maskell (1993). Illeris (1997) provides an empirical examination of employment data in 1970, 1982 and 1992 for the Copenhagen Metropolitan Area divided into central municipalities (Copenhagen and Frederiksberg) and the rest of the region. The examination covers a broad range of services from wholesaling to public administration. The data reveals that the employment in producer services and especially business services has increased tremendously between 1982 and 1992. The growth has mainly occurred outside the central municipalities (zones 1 and 2). Illeris (1997) concluded that not only did manufacturing and households services suburbanise in the 1980s and early 1990s but also most producer services. The national government administration, the head-offices of the larger organisations and banks, lawyer firms, advertising firms, hotels and theatres, however, remain highly concentrated in the centre of Copenhagen. This is explained by the need for easy face-to-face contact, the prestige, the historical environment, and the entertainments and tourist sights and accessibility by public transport. The suburbanisation of producer services (and other services industries) is divided into two main development paths. One path is a shift toward the western suburbs of Copenhagen, mainly among back-offices functions such as routine data processing and administration. Another development path is a shift towards the northern part of Copenhagen where consulting engineers and architects, high-skill computer and software services and other fast growing business services are located. This emphasises the thesis of the suburbanisation of services: the thesis applies for even the more knowledge intensive industries within business services. How did this evolve in the growth period of the 1990s? 


\section{The Transformation and Location Dynamics of Business Services 1982-2002}

Business services have become more important and today (2002) account for more than 14 percent of the employment in the urban landscape of Copenhagen. Table 1 shows the employment growth, shares and specialisation by zones. In order to have comparable data over a longer period of time, it was necessary to aggregate data; hence, business services are made up of NACE-codes 70-72 and 74 (Van Criekingen, 2004). Consequently, the sector includes real estate, computer processing and other business service activities, ranging from knowledge intensive consultancy to labour intensive, unskilled cleaning activities. The sector grew fast from 1982 to 2002 with close to a 130 percent increase in employment in the region. The growth rates also reveal that several shifts of location have occurred in the sector in the past decades with the growth rates being highest in zone 3 and especially zone 4 . However, as the table reveals, the share of regional employment is relatively modest in zone 4, close to 3.8 percent in 1982 only.

Table 1. Employment growth, regional shares and specialisation in business services by zones 1982-2002.

\begin{tabular}{|c|c|c|c|c|c|}
\hline & & $\begin{array}{l}\text { Zones } 1 \\
\text { and } 2\end{array}$ & Zone 3 & Zone 4 & Region \\
\hline \multirow[t]{3}{*}{ NACE-Codes $70-72,74$} & 1982 & 33.123 & 28.950 & 2.430 & 64.503 \\
\hline & 1992 & 39.224 & 44.190 & 4.255 & 87.669 \\
\hline & 2002 & 69.108 & 72.275 & 6.674 & 148.057 \\
\hline \multirow[t]{3}{*}{ Total employment } & 1982 & 404.316 & 459.202 & 64.671 & 928.189 \\
\hline & 1992 & 349.977 & 500.916 & 67.241 & 918.134 \\
\hline & 2002 & 378.804 & 553.111 & 75.040 & 1.006 .955 \\
\hline \multicolumn{6}{|l|}{ NACE-Codes $70-72,74$} \\
\hline & Growth $1982-2002 \%$ & 108,64 & 149,65 & 174,65 & 129,54 \\
\hline & Growth $1982-1992 \%$ & 18,42 & 52,64 & 75,10 & 35,91 \\
\hline & Growth $1992-2002 \%$ & 76,19 & 63,56 & 56,85 & 68,88 \\
\hline \multicolumn{6}{|l|}{ Total employment } \\
\hline & Growth $1982-2002 \%$ & $-6,31$ & 20,45 & 16,03 & 8,49 \\
\hline & Growth $1982-1992 \%$ & $-13,44$ & 9,08 & 3,97 & $-1,08$ \\
\hline & Growth 1992-2002 \% & 8,24 & 10,42 & 11,60 & 9,67 \\
\hline \multicolumn{6}{|l|}{ NACE-Codes 70-72, 74} \\
\hline & Share of regional employment $1982 \%$ & 51,35 & 44,88 & 3,77 & 100 \\
\hline & Share of regional employment $2002 \%$ & 46,68 & 48,82 & 4,51 & 100 \\
\hline \multicolumn{6}{|l|}{ Total employment } \\
\hline & Share of regional employment $1982 \%$ & 43,56 & 49,47 & 6,97 & 100 \\
\hline & Share of regional employment $2002 \%$ & 37,62 & 54,93 & 7,45 & 100 \\
\hline \multicolumn{6}{|l|}{ NACE-Codes $70-72,74$} \\
\hline & LQ 1982 & 1,2 & 0,9 & 0,5 & 1 \\
\hline & $\mathrm{LQ} 2002$ & 1,2 & 0,9 & 0,6 & 1 \\
\hline
\end{tabular}

SOURCE: STATISTIC DENMARK AND COMET DATABASES

An important fact of the transformation is that the patterns of growth and spatial restructuring are different in the period of recession compared to the period of growth. In the 1980s (1982-1992) the sector experienced high growth rates in employment compared to the over all growth patterns of the region, but growth rates were markedly lower than those of the economic boom in the 1990s. Further, there was a shift of the sector in the 1980s towards zones 3 and 4, with zone 4 having the highest growth rate - a process of decentralisation and suburbanisation of the sector (Illeris, 1997). The 1990s prove to have a different location dynamic. In the 1990s there was a shift in location of 
employment towards zones 1 and 2. This change in direction did not have the same effect as the shift in the 1980s. For this reason, zones 1 and 2 had a lower share of regional business services employment in 2002 than in 1982 while zones 3 and 4 both increased their shares.

Table 2 focuses on the period of growth (1994-2002) using two-digit NACE-codes? It provides a better insight of the changes. In Table 2, NACE-code 73, research and development, is included while real estate is excluded. This is done to focus on the more knowledge intensive parts of business services. In terms of employment, other business activities constitute the most important sector in the region and in all four zones account for more than 73 percent of business service employment in the region. This is a residual category that brings together legal activities, consultancy, advertising and cleaning, photographers, designers and translation, which makes it a much diverted category. Below it is examined in detail by using the level of formal education to differentiate it spatially.

Table 2. Business services employment growth, specialisation and regional shares by zones1994-2002.

\begin{tabular}{|c|c|c|c|c|c|c|}
\hline \multirow{2}{*}{ NACE-code 72} & \multicolumn{2}{|r|}{$\begin{array}{l}\text { Zones } 1 \\
\text { and } 2 \\
\end{array}$} & \multirow{2}{*}{$\begin{array}{r}\text { Zone } 3 \\
8082\end{array}$} & \multirow{2}{*}{$\begin{array}{r}\text { Zone } 4 \\
237\end{array}$} & \multirow{2}{*}{$\begin{array}{l}\text { Region } \\
11.854\end{array}$} & \multirow{2}{*}{$\begin{array}{c}\begin{array}{c}\text { Share of regional } \\
\text { Employment \% }\end{array} \\
14,3\end{array}$} \\
\hline & 1994 & 3535 & & & & \\
\hline Computer and Data Processing & 2002 & 11.338 & 16.333 & 596 & 28.267 & 20,4 \\
\hline Growth $1994-2002 \%$ & & 221 & 102 & 151 & 138 & \\
\hline \multicolumn{2}{|c|}{ Share of regional employment $2002 \%$} & 40 & 58 & 2 & 100 & \\
\hline NACE-code 73 & 1994 & 2.690 & 2.777 & 32 & 5.499 & 6,6 \\
\hline Research and Development & 2002 & 4.291 & 4.301 & 86 & 8.678 & 6,3 \\
\hline Growth $1994-2002 \%$ & & 60 & 55 & 169 & 58 & \\
\hline \multicolumn{2}{|c|}{ Share of regional employment $2002 \%$} & 49 & 50 & 1 & 100 & \\
\hline \multirow[t]{2}{*}{ NACE-code 74} & 1994 & 30800 & 31504 & 3474 & 65.778 & 79,1 \\
\hline & 2002 & 49590 & 46916 & 5067 & 101.573 & 73,3 \\
\hline Growth $1994-2002 \%$ & & 61 & 49 & 46 & 54 & \\
\hline \multicolumn{2}{|c|}{ Share of regional employment $2002 \%$} & 49 & 46 & 5 & 100 & \\
\hline \multirow[t]{2}{*}{ Total NACE-codes $72-74$} & 1994 & 37.025 & 42.363 & 3743 & 83.131 & 100,0 \\
\hline & 2002 & 65.219 & 67.550 & 5749 & 138.518 & 100,0 \\
\hline & & 76 & 59 & 54 & 67 & \\
\hline \multicolumn{2}{|c|}{ Share of regional employment $2002 \%$} & 47 & 49 & 4 & 100 & \\
\hline
\end{tabular}

SOURCE: STATISTIC DENMARK AND COMET DATABASES

Computer and data processing had the highest growth rates, increasing its share to more than 20 percent. Computer and data processing has shifted towards the core of the urban landscape but notably also towards zone 4 . This pattern is repeated in the case of research and development although it is mainly located in the built-up area of the urban landscape. Likewise, other business services activities have shifted towards the core of the city but with important growth rates in zones 3 and 4 .

Table 3 focuses on other business activities than NACE code 74. In order to get a better understanding of the division of labour in the urban landscape of Copenhagen, the municipalities in each zone are presented (the municipalities in zone 4 are excluded due to very small shares of regional employment). Further, to increase the knowledge of the division of labour, the number of employees with a university degree (ISCED 5A, 6) is presented in the table. This is used as an indication of the part of the business services which is knowledge-intensive, but only the part that uses formal education. As stated above, other business services are highly complex industries and the use of employees 
with university degrees can point to one of the central divisions of labour in the urban landscape of Copenhagen.

Table 3. Business services (NACE 74) employment and education, growth, specialisation and regional shares by zones 1994-2002.

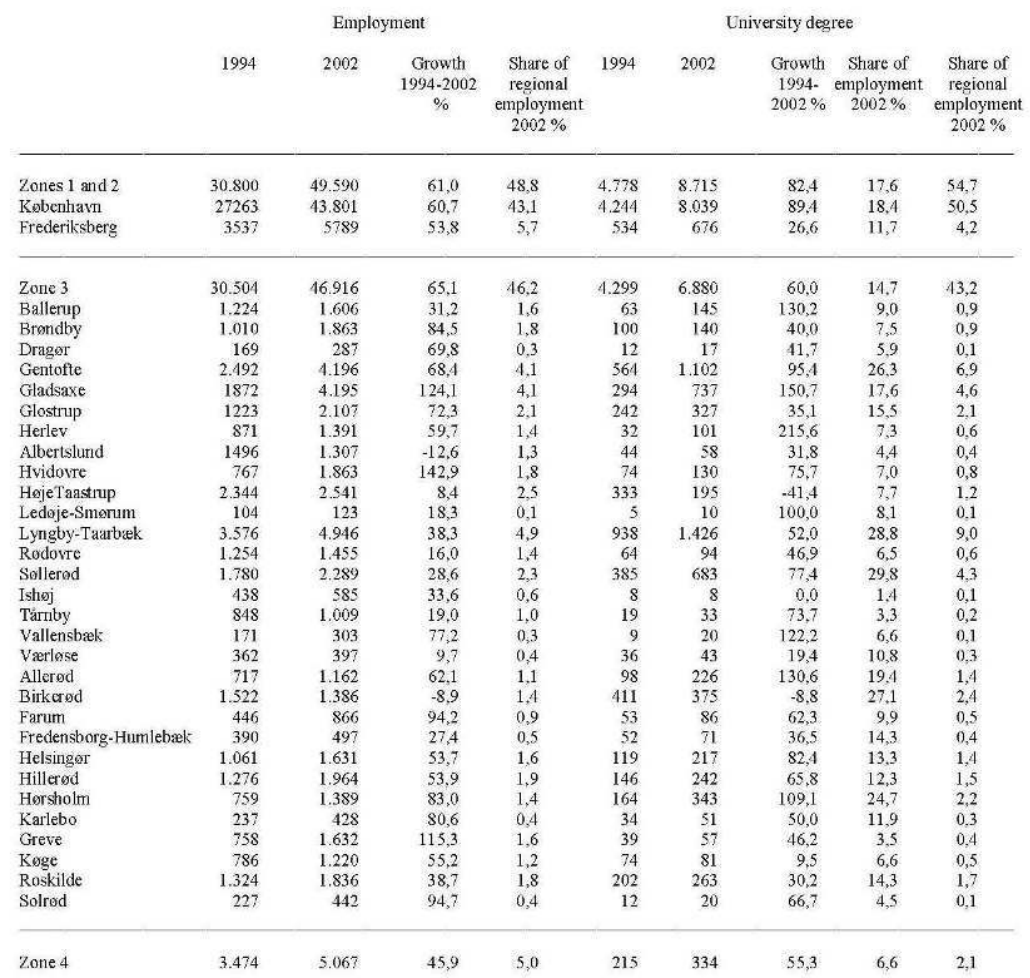

SOURCE: STATISTIC DENMARK AND COMET DATABASES

Other business service activities are mainly located in zones 1 and 2 which together account for close to 49 percent of the regional employment. Zone 3 accounts for more than 46 percent, leaving mere 5 percent to zone 4 . The growth in the 1990 s has been marked in all four zones but the highest rates are found in zone 3 and zones 1 and 2, indicating concentration in the built-up area of Copenhagen, mainly in the municipality of Copenhagen. Within zone 3 new patterns of location and concentrations are also produced. To a large extent concentrations are found in the northern municipalities, and in 2002, four municipalities (Gentofte, Gladsaxe, Lyngby-Taarbæk and Søllerød) accounted for 15.4 percent of regional employment and for 33.3 percent of the employment in zone 3. Further, the larger regional cities and centres such as Roskilde, Hillerød and Elsinore also had relatively high shares together with the municipalities dominated by back-office functions such as Ballerup and Høje-Taastrup.

In zone 3 the employment by workplace increased with more than 65\% from 1994-2002. The growth rates in table 3 reveal a spatial restructuring, and a shift in location was beginning in the period of investigation. With the exception of Gladsaxe, most northern municipalities had around and below regional average growth rates while some of the southern and western municipalities had high growth rates well above the average of the zone. This was evident in for instance Hvidovre, Greve and Solrød. Accordingly, a shift of the industry towards the southern and western parts of zone 3 has occurred. But what kind of business services have relocated? This would require more detailed data by 
industry to examine but the use of the share of employees with a university degree gives an indication of the location dynamics of the knowledge intensive business services by use of a formal educated labour force. Table 3 reveals that the share of employees with a university degree is highest, close to 18 percent, in zone 1 and 2 followed by zone 3 with a share of close to 15 percent. In zone 4 the share is more modest, only 6.6 percent. This indicates that the more knowledge-intensive businesses have a strong tendency to locate in the central parts of the urban landscape. This is further emphasised by the fact that zones 1 and 2 had the highest growth rates of employees with a university degree.

The pattern is emphasised by looking at the pattern in zone 3. The four northern municipalities identified above account for 25.4 percent of the regional employees with a university degree and have a share of 57.4 percent of the employees with a university degree in zone 3. In these municipalities, the share of employees with a university degree is very high, in some cases close to 30 percent. This is also the case in other northern municipalities, for instance Hørsholm, Birkerød and partly Allerød. The remaining municipalities have either close to the average share of employees with a university degree or in some cases even below the average of zone 4. This is evident in some of the western and southern municipalities. The growth rates support the conclusion of a strong concentration in the municipality of Copenhagen and the northern municipalities. Although some of the western and southern municipalities have had high growth rates, these municipalities are relatively unimportant in terms of absolute employment. It indicates, however, an upgrade of the use of a formal educated labour force in other parts of the urban landscape. It also emphasises the fact that a marked division of labour can be identified. The knowledge intensive parts of business services are concentrated in the central part of Copenhagen and in a string of northern municipalities, while other parts of the industry that do not depend on a high degree of a formal educated labour force are shifting towards the southern and western municipalities.

The pattern of the 1990s is in contrast with the more clearly suburbanisation process in the 1980s. It shows a higher degree of complexity of location and a revival of the central part of the urban landscape. Further, a spatial polarisation between the activities which require a high level of a formal educated work force and the remaining activities can be observed. Why do we see these new patterns of location? The next section will look into the firm's perception of location and location factors in order to provide evidence of the diversity of location dynamics in the sector.

\section{Location Preferences of Business Service Firms: Imaginary Spaces of Location}

To explore the imaginary spaces of location, the main results of a large European survey of location preference by service firms are used (Bachmann et al., 2003). The Danish part of the survey involved ten key industries - see Appendix - and included 182 service firms. 152 were located in zones 1, 2 and 3 and 30 in zone 4 . The case study of Copenhagen was performed in January and February 2003, and therefore it provides an insight into the firm's current perception of location and hence and indication of the complexity of the location dynamics in the 1990s. Interviews with representatives of the firms were conducted by telephone by students. The telephone interviews took place after appointments had been arranged with randomly selected firms. Prior to the date fixed for the interview, the questionnaires were sent by e-mail or fax to the selected and interested 
enterprises. The interviewer filled in the questionnaire himself/herself (prevention of mistakes, gaps etc.). The questionnaire included questions about the firm, the choice of location, future location plans and questions about networks and co-operations. In this section focus is on the five key industries that are characterised as business services and therefore relevant for the present analysis.

The five key industries chosen are matched against over all results of the survey presented in table 4 which reveals a list of the location factors by total rating of the firms. The list of preferences was divided into five main categories: location, traffic, labour and knowledge, market and partners and soft factors. These categories are based on an orthodox or neoclassical understanding of firm location in economic geography, but it also includes the results of various new perspectives that have been used as inspiration to explore the relational and geographical spaces of the firms.

Table 4. The Rating of Location Factors.

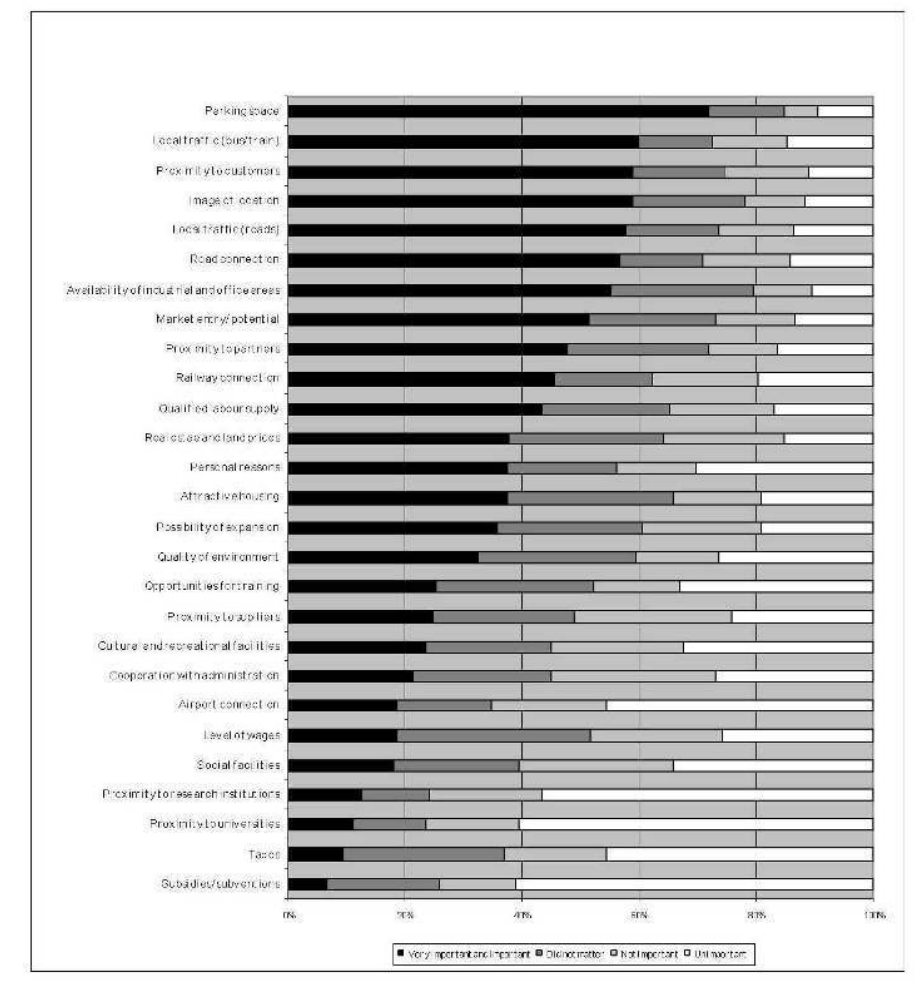

SOURCE: BACKMANN ET AL., 2003 AND THE COPENHAgEN SURVEY.

The main pattern of the ten key industries is that parking space was perceived as the most important location factor by the firms in the survey, followed by different mainly local traffic factors: proximity to costumers and the image of the location. Further down the list, market entry, proximity to partners and qualified labour appear with personal reasons and attractive housing following. Airport connections and proximity to research institutions and university were not imagined as important by the firms in the ten key industries together. In relation to the location dynamics of the ranking, the general conclusion is that the firms favour location in suburbia; here accessibility is higher than in the core of the urban landscape, zones 1 and 2. Why, then, do we see the revival and concentrations in 1990s? To get a better understanding of this and of the imaginary spaces of location of business services firms, five of the ten key industries have been 
chosen for analysis based on the results of Bachman et al. (2003). The key features are summarised below. The five key industries show the diversity and complexity of location and highlight some of the imagined advantages of for instance location in the central city - the numbers of the key industries refer to Appendix.

Key Industry 1: Research and Development: The industry differs significantly from the other industries and the average of all the firms in the survey. Features about the location such as real estate and land prices, availability of office areas and possible expansion are not relevant for the firms in this key industry. Traffic is important and is rated highly relevant by all firms in the survey; however, compared to the overall pattern, the industry puts emphasis on airport and railway connections while the importance of road connections, local traffic and parking space is below average and rated as unimportant for the location of the industry. This reveals the complexity of location dynamics of business service industries and of their perception of spaces of location.

Another important location factor for the industry is qualified labour, and, as the only industry, the firms rate proximity to research institutions and universities very highly while proximity to suppliers and partners is rated far below average. The industry generally regards the soft factors as unimportant and rates them around average. Hence, the industry's perception of location or imaginary space of location differs from the average perception. This will of course have an impact on the location dynamics of the firms in the industry and may favour locations close to universities and international traffic, which may explain one direction of the dynamics in 1990s - the concentration in the core and to the north.

Key Industry 2: Consulting Services: The industry is very different from the one above and consists of legal activities, accounting, book-keeping and auditing activities, tax consultancy, market research and public opinion polling together with business and management consultancy. The rating of the industry is very close to the average presented above which rated parking space as the most important location factor. The exception is that the firms rate international traffic access (airport and railway) higher than local traffic, indicating the international linkages of some parts of the industry. Further, market entry, proximity to partners and qualified labour along with personal reasons and attractive housing appear high on the list, again pointing to the diversity of the industry's imaginary spaces of location.

Key Industry 3: Technical and Engineering Services: The firms in the industry have high rankings of available office areas, airport and road connections while the rest of the traffic indicators are rated as unimportant. Qualified labour, however, is rated as more important than the average. In general, the firms rate proximity to market, customers, suppliers as unimportant but the firms rate proximity to partners highly and well above average while soft factors are relatively unimportant except from quality of the environment. To the firms in this industry, the perception of location is ambiguous but again different from the average as it is oriented towards different locations depending on the importance of the individual factor. It is worth noticing that proximity to partners are rated highly which indicates a location pattern that follows partners of the firms while qualified labour and airport connections may indicate a central location.

Key Industry 4: Blue Collar Business Services: The industry is different from the knowledge intensive business services included in the analysis. For instance it includes labour recruitment and provision of personnel, industrial cleaning and investigation and 
security activities. This is also evident in the firm's perception of location. The firms rate location related issues around average: traffic is interestingly rated below average and relatively unimportant while qualified labour is rated above average but far below key industry 1. Proximity to research institutions is rated as unimportant while the firms in the industry see proximity to market and customers as very important (the proximity to customers is the highest of all industries) while proximity to partners and soft factors are rated as unimportant and below average by the firms. The firms in the industry are oriented towards the market, giving more diverse location dynamics of the firms which points to especially zone 3 . As key industry 1 , the firms rate qualified labour high and above average. This illustrates the problem with absolute categories of location preferences. Based on the structure of the industries, qualified labour in key industries 1 and 4 are totally different categories but the understanding of labour as a vital input is perceived as important in both industries. However, it can provide completely different location dynamics in the urban landscape.

Key Industry 7: Telecommunication and Computers: The industry is made up of two very different industries: telecommunication which for instance located at the waterfront in the central city in the 1990s, while computer and data processing had a more diverse location pattern including zone 3. This produces an imaginary space of location that differs significantly from the other industries. The industry is the one that rates availability of office areas highest together with traffic, especially parking space but also local traffic (road, bus and train). Qualified labour and proximity to knowledge institutions are not important but the opportunities for training are regarded to be more important than the average. Further, proximity to market, customers, suppliers and partners are rated higher than the average and especially market, customers and partners are of importance. Further, the image and prestige of the location are rated highly important. In Hansen et al. (2003) it is suggested that business to business activities in the industry are oriented towards zone 3 while business to consumers has an orientation towards the inner city and waterfront. This also points to the fact that images of locations are very different between the industries.

The business service industries of the 1990s have very different imaginary spaces of location. This explains the more differentiated pattern of location dynamics in the 1990s. The core of the urban landscape again gained jobs in business services. Existing locations expanded in zone 3 but new growth patterns were evident with zones 3 and 4 as well. It also points to a more profound division of labour between locations in the urban landscape and hence a polarisation between and within industries. We need to investigate how the firm and decision makers of the firm produce their representation of space. Additionally, we need to understand how the social and cultural embeddedness of economic action produces the firm's imaginary spaces of location.

\section{Conclusions}

The resurgence and expansion of the city-region in the past decade have resulted in new location dynamics and shifts in location of business services. One of the questions of the paper was: what are the main growth patterns and location shifts of business services in Copenhagen? The conclusion is that the growth pattern in 1990s was markedly different from the pattern produced in the 1980s where the growth was mainly in the suburban zone. In the 1980s business services experienced high growth rates in employment 
compared to the over all growth patterns of the region, but markedly lower than the growth rates in the 1990s. Further, there was a shift of the sector in the 1980s towards zones 3 and 4, with zone 4 having the highest growth rate. The 1990s prove to have a different location dynamic. In the 1990s there was a shift in location of employment towards zones 1 and 2. This change in direction did not have the same effect as the shift in the 1980s. For this reason the central city, zones 1 and 2, had a lower share of regional business services employment in 2002. The location pattern of business services in 1990s was therefore in contrast to the suburbanisation process in the 1980s. It generally showed a higher degree of complexity. The revival of the central part of the urban landscape was present but also an expansion of existing centres in suburbia and a shift towards new locations in the urban landscape occurred.

Focussing on NACE 74 - other business services that range from consultancy to cleaning it is clear that the industry has a strong concentration in the central city and in zone 3 . The growth in the 1990s has been strong in all four zones, but the highest rates are found in zone 3 and zones 1 and 2, indicating concentration in the built-up area of Copenhagen, mainly in the municipality of Copenhagen. Within zone 3 new patterns of location and concentrations has been produced. The northern municipalities had around and below regional average growth rates while some of the southern and western municipalities had high growth rates, well above the average of the zone. Accordingly, there has been a shift of the industry towards the southern and western parts of zone 3. But what kind of business services have relocated? Using the share of employees with a university degree, an indication of the location dynamics of the knowledge intensive business services was provided by use of a formal educated labour force. The share of employees with a university degree is highest in zone 1 and 2 followed by zone 3. In zone 4 the share is modest. This indicates that the more knowledge intensive businesses have a strong tendency to locate in the central parts of the urban landscape.

In northern municipalities the share of employees with a university degree is very high in some cases close to 30 percent. The remaining municipalities either have a share of employees with a university degree close to the average or far below the average. This is evident in some of the central western and southern municipalities. The growth rates support the conclusion of a strong concentration in the municipality of Copenhagen and the northern municipalities. Although some of the western and southern municipalities have had high growth rates, these municipalities are relatively unimportant in terms of absolute employment. It indicates, however, an upgrade of the use of a formal educated labour force in other parts of the urban landscape. It also emphasises the fact that a marked division of labour can be identified. The knowledge intensive parts of business services are concentrated in the central part of Copenhagen and in a string of northern municipalities while other parts of the industry that do not depend on a high degree of formal educated labour force are shifting towards the southern and western municipalities. It seems that labour, education and knowledge intensity has strong implication for the different dynamics of the 1980s and 1990s.

To provide further evidence of the more multifaceted location of the 1990s, the location preferences of the firms were conceptualised as imaginary spaces of location. The imaginary spaces of location are social constructs based on personal beliefs and discursive practice. The imaginary spaces of location can be related to a variety of discourses arising from multiple rationalities, including social and cultural embedded rationalities. The business service industries have very different imaginary spaces of 
location. This adds to the explanation of the more differentiated pattern of location dynamics in the 1990s. The firms, divided by industry and zone, have quite different representations of their economic spaces. Obviously, this has an impact on the location of the firms and the spatial dynamics. There is therefore a need to further investigate how the firms and decision makers of the firms produce their representation of space. We need to understand how the social and cultural embeddedness of economic action produces the firm's imaginary spaces of location. Moreover, there is a need to elaborate on its importance for the spatial restructuring. How are the firm's imaginary spaces involved in producing location dynamics?

\section{BIBLIOGRAPHY}

AMIN A. (2003) “Spaces of Corporate Learning”, in PECK J. \& YEUNG H. (eds.) Remaking the Global Economy: Economic Geographical Perspectives, London, Sage, pp. 114-129.

AMIN A. (2004), “Regions Unbound. Towards a New Politics of Place”, Geografiska Annaler, 86B(1), pp. 33-44.

AMIN A. \& COHENDET P. (2004), Architectures of Knowledge. Firms, Capabilities, and Communities, Oxford, Oxford University Press.

AMIN A. \& THRIFT N. (2002), Cities. Reimagining the Urban, Cambridge, Polity.

ANDERSEN H.T., HANSEN F. \& JøRGENSEN, J. (2003), “The rise and fall of metropolitan government in Copenhagen", Geojournal, 58, pp. 43-52.

ASCHER F. (2002) "Urban Homogenisation and Diversification in West Europe", in HAMBLETON R., SAVITCH H. V. \& STEWART M. (eds.) Globalism and Local Democracy. Challenge and Change in Europe and North America, Houndsmill, Palgrave Macmillan, pp. 52-66.

ASHEIM B. T. (1996), “Industrial Districts as 'Learning Regions': a Condition for Prosperity”, European Planning Studies, 4, pp. 379-400.

ASHEIM B., COOKE P. \& MARTIN R. (eds.) (2006), Clusters and regional Development. Critical reflections and explorations, London, Routledge.

ASHEIM B. T. \& MARIUSSEN (2003), Innovations, regions and projects - studies in new forms of knowledge governance, Report 2003-3, Stockholm, Nordregio.

BACHMANN M., BIOT V., VAN CRIEKINGEN M., HAGSPIEL E., HANSEN H., JøRGENSEN J., KUFFER

M., LENNERT M., LUZÓN J. L., MAIERBRUGGER G, MAJOOR S., VAN OOSTEREN C. PÖCKL A., RUBIO F., SCHIMMEL E. STORGAARD A., VILA J., WACKERMANN G., WENDEL J. \& WINTHER L. (2003), Enquiry of Enterprises - Final Report, Berlin, Free University of Berlin.

BARNES T. (1996), Logics of Dislocation. Models, Metaphors, and Meanings of Economic Space, New York, Guilford Press.

BATHELT H., MALMBERG A. \& MASKEL P. (2004), “Clusters and Knowledge - Local Buzz, global pipelines and the process of knowledge creation", Progress in Human Geography, 28, pp. 31-56. 
BELL D. (1999), The Coming of Post-industrial Society - A Venture in Social Forecasting, New York, Basic Books.

BONTJE M. (2004), "From suburbia to post-suburbia in the Netherlands: Potentials and threats for sustainable regional development", Journal of Housing and the Built Environment, 19, pp. 25-47.

BORSDORF A. (2004), "On the Way to Post-Suburbia? Changing structures in the outskirts of European Cities", in BORSDORF A. and ZEMBRI P. (eds.) (2004), Structures. European Cities. Insights on Outskirts, Brussels, cosT Office, pp. 7-30.

BORSDORF A. \& ZEMBRI P. (eds.) (2004), Structures. European Cities. Insights on Outskirts, Brussels, COST Office.

BREUM J. (1991), Industriel fornyelse og industriens regionale udvikling, København, Rapport nr. 60., Institut for Veje, Trafik og Byplan, Danmarks Tekniske Højskole.

COOKE P. and MORGAN K. (1998), The Associational Economy. Firms, Regions and Innovation, Oxford, Oxford University Press.

VAN CRIEKINGEN M., GUISSET C., BIOT V. and VANDERMOTTEN C. (2004), Spatial Dynamics of Service Activities in European Metropolitan Areas. Lessons from the Comparison of the COMET Case Studies , Report, Brussels, IGEAT - Université Libre de Bruxelles.

DAVID P. A. and FORAY D. (2002), “An Introduction to the Economy of the Knowledge Society”, International Social Science Journal, 54, 171, pp. 9-23.

EDQUIST C. (1997), Systems of Innovation, London, Pinter.

ETTLINGER N. (2003), “Cultural economic geography and a relational and microspace approach to trust, rationalities, networks, and change in collaborative workplaces", Journal of Economic Geography, 3, pp. 145-171.

FICH C. \& LARSEN H. (1988), City-orienterede virksomheder, København, Institut for Veje, Trafik og Byplan, Danmarks Tekniske Højskole.

GERSHUNY J. (1978), After Industrial Society? The Emerging of Self-service Economy, London, The MacMillan Press Ltd.

GERTLER M. (2003), "The spatial life of things: the real world of practice within the global firm", in PECK J. \& YEUNG H. (eds.) Remaking the Global Economy: Economic Geographical Perspectives, London, Sage, pp. 101-113.

HANSEN H. K., JøRGENSEN J. \& WINTHER L. (2003), “Copenhagen”, Comet End \& Government Users, 2, pp. 3-5.

HIDDING M., NEEDHAM B. \& WISSERHOF J. (2000), “Discourses of Town and Country”, Landscape and Urban Planning, 48, pp. 121-130.

ILLERIS S. (1987a), Service og lokal erhvervsudvikling, Copenhagen, AKF's Forlag.

ILLERIS S. (1987b), “Service og regional udvikling”, Geografisk Tidsskrift, 87, pp. 27-36.

ILLERIS S. (1996), The Service Economy, West Sussex, John Wiley \& Sons Ltd.

ILLERIS S. (1997), "The Changing Location of Service Activities in the Copenhagen Region", Geografisk Tidsskrift, 97, pp. 120-142.

JAKOBSEN L. (1993), "Start-up of New High-Tech Firms and the Role of the Regional Industrial Environment - the Case of Denmark", in LORENTZEN et al. (eds.), Teknologiudvikling og regional forandring, København, AKF Forlaget, pp. 65-80. 
KLOOSTERMAN R. C. and MUSTERD S. (2001), “The Polycentric Urban Region: Towards a Research Agenda", Urban Studies, 38, 4, pp. 623-633.

LUNDVALL B.-Å. (1992), National Systems of Innovation, London, Pinter

MARTIN R. \& SUNLEY P. (2003), “Deconstructing clusters: chaotic concept or policy panacea?”, Journal of Economic Geography, 3, pp. 5-35

MASKELL P. (1986), Industriens flugt fra storbyen: årsager og konsekvenser, København, Handelshøjskolens Forlag.

MASKELL P. (1993), Liberale erhverv i hovedstadsregionen og deres betydning for ejendomsmarkedet, Frederiksberg, Samfundslitteratur.

MASKELL P. \& MALMBERG A. (1999), “The Competitiveness of Firms and Regions: 'Ubiquitification' and the Importance of Localized Learning”, European Urban and Regional Studies, 6, pp. 9-25

MORGAN K. (1997), “The Learning region: Institutions, Innovation and Regional Renewal”, Regional Studies, 31, pp. 491-503

NIELSEN C. B. \& PLANSTYRELSEN (1988), Forretningsservice. Regionalgeografisk udvikling 1980-84, Copenhagen, Planstyrelsen.

NIELSEN,C. B. \& SØRENSEN P. M. (1987), “Den regionale udvikling - specielt indenfor erhvervsservice”, in PEDERSEN J. S. \& SUNDBO J. (eds.) Service - et spil om fremtid, Copenhagen, Samfundslitteratur, pp. 63-79.

N.U.R.E.C. (1994), Atlas of Agglomerations in the European Union, Duisburg, NUREC.

PECK J. and YEUNG H.-W. (2003), Remaking the Global Economy: Economic Geographical Perspectives, London, Sage.

PEDERSEN P. O. (1986), Erhvervsservice strategier - en undersøgelse af erhvervsservice i Esbjerg, Esbjerg, Sydjysk Unversitetsforlag.

PHELPS N. A. \& PARSONS N. (2003), “Edge Urban Geographies: Notes from the Margins of Europe's Capital Cities”, Urban Studies, 40, 9, pp. 1725-1749.

SCOTT A. J. (ed.) (2002), Global City-Regions. Trends, Theory, Policy, New York, Oxford University Press.

SIEVERTS T. (2003), Cities without Cities. An Interpretation of the Zwischenstadt, London, Spon Press.

STORPE, M. (1997), The regional world. Territorial Development in a Global Economy, New York, Guilford.

STORPER M. \& MANVILLE M. (2006), "Behavior, Preferences and Cities: Urban Theory and Urban Resurgence”, Urban Studies, 43, 8, pp. 1247-1274

WINTHER L. (2001), “The Economic Geographies of Manufacturing in Greater Copenhagen: Space, Evolution and Process Variety”, Urban Studies, 38, pp. 1423-1444.

WINTHER L. (2004), “Storbylandskabets grænseoverskridende økonomi”, in ANDERSEN H. S. \& ANDERSEN H. T. (eds.), Den mangfoldige by - opløsning, oplevelse, opsplitning, Hørsholm, SBI, pp. 54-75.

WINTHER L., ALBERTSEN N., ANDERSEN H. T. \& BAYLISS D. (2005), Cities and the knowledge-based economy, TAPAS Working Paper 2005 03, København, Department of Geography, University of Copenhagen. 
WINTHER L. \& HANSEN H. K. (2006), “The Economic Geographies of the Outer City: Industrial Dynamics and Imaginary Spaces of Location in Copenhagen", European Planning Studies, 14(10), pp. 1387-1406.

\section{APPENDIXES}

THE TEN KEY INDUSTRIES OF THE SURVEY

Source : Bachmann et al. (2003)

\begin{tabular}{|c|c|c|c|}
\hline \multicolumn{2}{|c|}{ Key Branches } & \multirow{2}{*}{$\begin{array}{l}\begin{array}{l}\text { NACE- } \\
\text { Code }\end{array} \\
73.1\end{array}$} & \multirow{2}{*}{$\begin{array}{l}\text { Description } \\
\text { Resesrch and experimental cevelopment on natural sciences and } \\
\text { engineering }\end{array}$} \\
\hline 1 & $\begin{array}{l}\text { Research \& } \\
\text { Development }\end{array}$ & & \\
\hline & & 73.2 & $\begin{array}{l}\text { Research and experimental cevelopment on social sciencos and } \\
\text { humanites }\end{array}$ \\
\hline \multirow[t]{2}{*}{2} & Consulting services & 74.1 & $\begin{array}{l}\text { Legal, accounting, book-keep ing and auciting ectivities; tex consultancy; } \\
\text { market research and public opinion polling; business and management } \\
\text { consutancy; holdings }\end{array}$ \\
\hline & & 74.4 & Advertising \\
\hline \multirow[t]{2}{*}{3} & Technical \& & 74.2 & Architectural anc engineering act vites and related techn cal consultancy \\
\hline & & 74.3 & Techrical testing and analysis \\
\hline \multirow[t]{4}{*}{4} & Predominantly & 74.5 & Labour recruitment and provision of personnel \\
\hline & blue-collar & 74.6 & Irvestigation and security activities \\
\hline & business services & 74.7 & Industrial cleaning \\
\hline & & 74.8 & Miscelleneous business activities n.e.c. \\
\hline \multirow[t]{5}{*}{5} & Finance \& Insurance & 65.1 & Monetary intermediation \\
\hline & & 65.2 & Other f nencial intermediation \\
\hline & & 66.0 & Insurance and pension funding, except compulsory social security \\
\hline & & 67.1 & $\begin{array}{l}\text { Act vites auxliary to financial intermediation, except insurance and } \\
\text { persion furding }\end{array}$ \\
\hline & & 67.2 & Act vites aux liary to insurence and pension funding \\
\hline \multirow[t]{3}{*}{6} & Real Estate & 70.1 & Real estate activities with own property \\
\hline & & 70.2 & Letting of own property \\
\hline & & 70.3 & Real estate activities on a tee or contract basis \\
\hline \multirow[t]{7}{*}{7} & \multirow{7}{*}{$\begin{array}{l}\text { Telecommunications, } \\
\text { Computer \& } \\
\text { Electronic } \\
\text { data processing }\end{array}$} & 64.2 & Telecommunications \\
\hline & & 72.1 & Hardware consultancy \\
\hline & & 72.2 & Soitware consultancy and supoly \\
\hline & & 72.3 & Data processing \\
\hline & & 72.4 & Database activities \\
\hline & & 72.5 & Maintenance and repsir of office, accounting and computing machinery \\
\hline & & 72.6 & Other compurer related activities \\
\hline \multirow[t]{4}{*}{8} & \multirow{4}{*}{ Press \& Media } & 92.1 & Motion picture and video activities \\
\hline & & 92.2 & Racio and te levision activtles \\
\hline & & 92.4 & News agency act vites \\
\hline & & 22.1 & Publisting \\
\hline \multirow[t]{2}{*}{9} & \multirow{2}{*}{$\begin{array}{l}\text { Culture \& } \\
\text { Enterianment }\end{array}$} & 92.3 & Other enterta inment activitios \\
\hline & & 92.7 & Other recreational sctivitos \\
\hline \multirow[t]{3}{*}{10} & \multirow{3}{*}{$\begin{array}{l}\text { Activities of Membership } \\
\text { Organ sations n.e.c. }\end{array}$} & 91.1 & Actvites of business, employers' and professional organizations \\
\hline & & 91.2 & Actvites cf trade unions \\
\hline & & 91.3 & Activites of other membership organizations \\
\hline
\end{tabular}

\section{NOTES}

1. COMET was coordinated by the Institute for Urban and Regional Research, Austrian Academy of Sciences, Vienna, and financially supported by the European Commission, DG Research, $5^{\text {th }}$ Framework Program, Key Action "The City of Tomorrow and Cultural Heritage" (Project no. VK4_CT_2001_00050), www.comet.ac.at 


\section{ABSTRACTS}

The paper examines the current transformation and spatial restructuring of the urban economy with focus on the location dynamics of business services, especially during the past decade of economic growth. Since the early 1990s, Copenhagen has experienced economic growth and job creation created mainly by the service industries, including the rise of knowledge intensive business services. The location dynamics of the 1990s growth were more ambiguous than the patterns of the 1980s. The location in the 1990s involved both a concentration in the central part of the urban landscape, an extension of existing locations in suburbia and growth in new locations in the urban landscape. The paper provides empirical evidence of the new complexity of location dynamics and introduces imaginary spaces of location to explain the diversity of location. Imaginary spaces of location are social construction of firms based on the perception, experience and interpretation of the firm's location.

Cet article examine les mutations actuelles ainsi que les restructurations spatiales de l'économie urbaine, et tout spécialement les dynamiques de localisation des services aux entreprises, en particulier au cours de la dernière décennie de croissance économique. Depuis le début des années 90, Copenhague a connu une croissance économique et des créations d'emplois principalement dans les industries de services, en ce compris une augmentation des services d'expertise. Les dynamiques de localisation des années 90 étaient plus ambiguës que celles de la décennie précédente, car elles impliquaient à la fois une concentration dans la partie centrale du paysage urbain, une extension des localisations existantes dans la périphérie, et de nouvelles localisations dans le paysage urbain. Cet article apporte une preuve empirique de la nouvelle complexité des dynamiques de localisation et présente des espaces imaginaires de localisation pour en expliquer la diversité. Ces espaces sont une construction sociale basée sur la perception, l'expérience et l'interprétation de la localisation des entreprises.

\section{INDEX}

Mots-clés: dynamiques de localisation, paysage urbain, services aux entreprises, compétitivité, localisations de prédilection

Keywords: location dynamics, urban landscape, business services, competitiveness, preferences of location

\section{AUTHOR}

\section{LARS WINTHER}

Institute of Geography, University of Copenhagen, Øster Voldgade 10, DK-1350 Copenhagen K, lw@geogr.ku.dk 